\section{MELODI DAN LIRIK LAGU CAMPURSARI CIPTAAN MANTHOUS}

\section{Kusnadi}

\section{FBS Universitas Negeri Yogyakarta}

\section{Abstract}

Campursari songs are specific phenomena in music development and Javanese traditional music. Based on forms, campursari songs composed by Manthous still refer to traditional music and songs, especially the conventional ones, lelagon dolanan, or mixture between them. The most dominant literary decoration applied in his song lyrics are purwakanthi guru swara parikan,

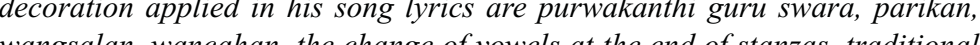
expressions, sengh expressions, senggakan and bebasan parbasan. The most dom inan themes are love, marriage life, beauty of nature and social life. All are in accordance with the target of andience, namely youths and adults.

Keywords: melody, lyrics, campursari song

\section{A. Pendahuluan}

Musik campursari adalah suatu yang fenomenal dalam sejarah perkembangan musik di Indonesia. Campursari adalah salah satu bentuk kreas musik yang diciptakan oleh Manthous pada tahun 1993. Jenis musik ini mempergunakan instrumen gabungan antara instrument musik diatonis Barat (keyboard) dengan gamelan Jawa yang dibuat secara khusus dengan menggunakan frekuensi musik Barat sehingga bunyi yang ditimbulkan dari penggabungan tersebut terasa menjadi lebur.

Sejak dicetuskan pada tahun 1993, musik campursari mendapat sambutan yang baik dari masyarakat. Begitu populernya jenis musik ini, pada tahun 90 -an terjadi trend terbentuknya group-group campursari dimana-mana sampai ke pelosok-pelosok pedesaan. Pemunculan jenis musik ini merambah juga di berbagai media elektronik seperti radio, televisi, dan hadir di berbagai kesempatan baik pada acara-acara formal maupun santai.

Lagu-lagu yang dinyanyikan dalam musik campursari dikenal dengan nama lagu campursari. Sudah banyak lagu-lagu campursari yang diciptakan oleh para seniman seperti Anjar Ani, Darmanto, Didi Kempot, dan sebagainya, akan tetapi objek kajian ini dibatasi pada lagu-lagu campursari ciptaan Manthous yang dipublikasikan secara luas melalui media VCD, baik yang dilantunkan sendiri oleh Manthous maupun oleh penyanyi lain semenjak tahun 1993 sampai tahun 2003.

Berdasarkan hasil studi pelacakan, ditemukan 26 judul lagu campursari ciptaan Manthous yang tergabung dalam 5 album VCD campursari, yaitu: (1) Aneka Campursari Karaoke produksi Dasa Studio (2) Seleksi Aneka
Campursari Vol 2 Karaoke produksi Dasa Studio (3) Campursari I karya Manthous produksi Cakrawala Musik Nusantara, (4) Aneka Campursari CSGK produksi Dasa Studio, dan (5) CSGK 2000 produksi Boulevard Indonesia. Secara terperinci judul-judul lagu tersebut adalah sebagai berikut

\section{Tabel 1 Judul Lagu-lagu Campursari Ciptaan Manthous}

\begin{tabular}{|c|c|c|c|}
\hline No. & JUDUL LAGU & JUDUL ALBUM & PRODUKSI \\
\hline $\begin{array}{l}1 . \\
2 . \\
3 .\end{array}$ & $\begin{array}{l}\text { Bengawan Sore } \\
\text { Kempling } \\
\text { Ojo Digondheli }\end{array}$ & Aneka Campursari Karaoke & Dasa Studio 1995 \\
\hline 4. & Ojo Gawe-gawe & Aneka Campursari Karaoke Vol 2 & Dasa Studio 1995 \\
\hline 5. & Tahu Apa Tempe & Aneka Campursari CSGK & Dasa Studio \\
\hline \begin{tabular}{c|}
6. \\
7. \\
8. \\
9. \\
10. \\
11. \\
12. \\
13. \\
14. \\
15. \\
16.
\end{tabular} & $\begin{array}{l}\text { Gethuk } \\
\text { Kangen } \\
\text { Langgam Kanca Tani } \\
\text { Pripun } \\
\text { Gunung Kidul } \\
\text { Andheng-andheng } \\
\text { Anting-anting } \\
\text { Klemben-klemben Roti-roti } \\
\text { Pipa Landa } \\
\text { Nginang Karo Ngilo } \\
\text { Simpang Lima }\end{array}$ & $\begin{array}{l}\text { Campursari I karya Manthous } \\
\text { oleh Waljinah }\end{array}$ & $\begin{array}{l}\text { Cakrawala Musik } \\
\text { Indonesia }\end{array}$ \\
\hline $\begin{array}{l}17 . \\
18 . \\
19 . \\
20 . \\
21 . \\
22 . \\
23 . \\
24 . \\
25 . \\
26 .\end{array}$ & $\begin{array}{l}\text { Sido Apa Ora } \\
\text { Parangtritis } \\
\text { Methuk } \\
\text { Esemmu } \\
\text { Sluman-slumun Slamet } \\
\text { Othok Kowouk } \\
\text { Lega } \\
\text { Kembang Kecubung } \\
\text { Mbah Dukun } \\
\text { Geblek Kulon Progo }\end{array}$ & CSGK 2000 & Boulevard Indonesia \\
\hline
\end{tabular}

Suatu nyanyian sesungguhnya merupakan perpaduan yang serasi antara tembang (lagu) dan tembung (sastra). Baik buruknya perpaduan dua aspek tersebut akan menentukan kualitas suatu nyanyian. Dengan kata lain, kekuatan suatu nyanyian terletak pada dua hal tersebut, yaitu (1) kualitas komposisi lagunya, dan (2) kualitas sastranya. Tulisan berikut ini berusaha untuk mengkaji bentuk lagu campursari khususnya pada aspek melodi dan liriknya dari perspektif tembang Jawa. 


\section{B. Pengembangan Aspek Melodi}

Menurut Atmadarsana, (1956:7), studi tentang lagu meliputi tiga bidang garapan, yaitu (1) melodi, (2) ritme, dan (3) harmoni. Melodi adalah susunan yang serasi nada-nada yang tinggi dan nada-nada yang rendah dalam suatu komposis nada. Dalam suatu lagu, nada-nada bergelombang naik dan turun yang akhirnya kembali ke dataran semula. Ritme adalah pengulangan-pengulangan irama yang teratur dari kombinasi nada-nada panjang dan pendek. Harmoni berart keselarasan (Prier, 2001:3). Dalam konteks suatu lagu, harmoni berarti keselarasan nada-nada ketika nada-nada tersebut dibunyikan bersama-sama atau dipadukan.

Penyusunan suatu melodi lagu dalam perspektif tembang Jawa setidaktidaknya mempertimbangkan empat hal, yaitu (1) laras (tangga nada), (2) pathe (pengaturan fungsi nada), (3) cengkok dan wiled, dan (4) struktur bentuk serta karakter lagu. Keempat hal tersebut di atas akan dijadikan dasar untuk melihat fenomena yang terjadi pada lagu-lagu campursari ciptaan Manthous.

\section{Laras}

Dalam konteks karawitan dan tembang Jawa, istilah laras mengandung dua kemungkinan makna. Yang pertama, laras berarti nada atau suara yang enak di dengar. Pada pengertian ini, yang dimaksud dengan laras adalah nada-nada yang dipergunakan dalam karawitan Jawa, yaitu panunggul, gulu, dhadha, lima, nem pelog, dan barang. Pengertian yang kedua, laras diartikan sebagai tangga nada, yakni urutan nada dalam satu gembyangan (oktaf) yang sudah tertentu sruti-sruti (interval)nya. Pada uraian selanjutnya, istilah laras yang dimaksudkan adalah yang mengacu pada pengertian yang kedua.

Secara umum dalam karawitan Jawa dikenal adanya dua laras, yaitu pelog dan slendro. Akan tetapi, sesungguhnya dari perspektif tembang (vokal) Jawa terdapat empat laras dalam tembang Jawa yaitu slendro, barang miring, pelog bem, dan pelog barang. Karakteristik masing-masing laras tersebut di atas dapat diuraikan sebagai berikut

\section{a. Laras Slendro}

Laras slendro adalah suatu tangga nada pada seni karawitan yang menggunakan lima nada yang dihasilkan dari perangkat gamelan slendro. Kelima nada tersebut adalah barang ( $1=$ baca ji), gulu ( $2=$ baca ro), dhadha ( $3=$ baca lu), lima $(5=$ baca $\mathrm{ma})$, dan enem $(6=$ baca nem $)$.

Secara teoretik, sruti-sruti dalam laras slendro dari masing-masing nada tersebut adalah sama, meskipun kenyataannya sruti-sruti tersebut berbeda. (Baca: Suryadiningrat, 1993). Jarak antara nada-nada terdekat adalah 240 cent.

Laras slendro disajikan dalam tiga kemungkinan pathet (nada dasar), yaitu pathet sanga (tonikanya nada 5), pathet nem (tonikanya nada 2), dan pathet

Imaji, Vol.4, No.1, Februari $2006: 100$ - 113 manyura (tonikanya nada 6). Dari aspek lagu, penyajian gendhing atau lagu dengan pathet sanga dan pathet manyura mempunyai karakteristik lagu yang sama. Perbedaannya, pada pathet manyura nada-nadanya satu tingkat (nada) lebih tinggi. Sedangkan pada pathet nem, karakteristik lagunya agak berbeda.

\section{b. Laras Barang Miring}

Dari aspek struktur iringan musiknya, laras barang miring sama dengan laras slendro. Perbedaan keduanya terletak pada vokal atau tembang yang dilantunkan. Pada laras barang miring banyak ditemukan nada-nada miring (minir), yaitu nada slendro yang dinaikkan setengah nada. Nada miring tersebut tidak terjadi pada semua nada, akan tetapi hanya pada beberapa nada saja yang penotasiannya biasanya dilambangkan dengan nada slendro yang dicoret miring.

c. Laras Pelog Bem

Laras pelog bem adalah tangga nada dalam karawitan dan tembang Jawa yang menggunakan nada-nada 6123456 yang dihasilkan dari perangkat gamelan pelog (tidak menggunakan nada 7 , kecuali dalam komposisi pamijen). Nama nadanadanya sama dengan laras slendro kecuali nada 1 disebut nada penunggul atau bem dan nada 4 yang disebut nada pelog. Lagu-lagu yang menggunakan laras pelog bem bisa disajikan dalam dua kemungkinan pathet, yaitu pathet lima (tonikanya nada 5), dan pathet nem (tonikanya nada 2).

\section{d. Laras Pelog Barang}

Laras pelog barang adalah tangga nada dalam tembang Jawa yang menggunakan nada-nada 6723456 yang dihasilkan dari perangkat gamelan pelog (tidak menggunakan nada 1 , kecuali dalam komposisi pamijen). Nada 7 (baca: pi) disebut nada barang. Lagu-lagu yang menggunakan laras pelog barang disajikan dalam satu pathet, yaitu pathet barang

\section{Pathet dalam Tembang Jawa}

Istilah pathet menyiratkan beberapa pengertian. Pada seni tembang, istilah pathet bisa disejajarkan dengan kunci pada musik diatonis Barat. Suatu pathet akan menentukan nada dasar dan ambitus (jangkauan nada) suatu lagu yang dihidangkan. Pada seni pedalangan, istilah pathet menunjuk pada waktu. Gendhing-gendhing yang dihidangkan dalam seni pedalangan sudah diatur waktunya. Pada seni karawitan secara umum, istilah pathet mengandung arti garap. Bila terjadi perpindahan pathet berarti terjadi perpindahan garap (Martopangrawit, 1972: 49).

Secara teoretik, pathet adalah tugas nada dalam suatu laras (Siswanto, 1978: 8) Suatu lagu dilukiskan sebagai suatu arus nada yang menggelombang naik, turun, mendatar, mendekati atau menjauhi suatu pusat. Pusat lagu itu biasa disebut dengan istilah dhong (Barat: tonika). Dalam karawitan Jawa, dhong/tonika ini biasanya ditandai dengan gong ageng. Nada yang berfungsi sebagai nada dhong 
adalah nada yang paling penting dan paling kuat dalam suatu pathet. Nada-nada yang lain mempunyai fungsi dan tingkat ketegangan yang berbeda dengan tonika. Fungsi nada yang lain adalah: dhang (Barat: dominant), dhung (Barat: subdominant), dhing (nada penyalur bawah), dan dheng (nada penyalur atas) Sebagai contoh, dalam laras Pelog pathet Lima, nada dhong=5, dhung=1 dhang $=2$, dhing $=4$, dan dheng $=6$. Secara skematis fungsi nada dalam suatu pathet dapat digambarkan sebagai berikut (semakin ke tengah, fungsinya semakin penting).

\begin{tabular}{|l|l|l|l|l|l|}
\hline Dhing (i) & - Dhung (u) & - & \multicolumn{2}{|l|}{ Dhong (o) } & \multicolumn{2}{|l|}{ Dhang (a) -} & Dheng (e) \\
\hline
\end{tabular}

\section{Gambar 3. Fungsi Nada dalam Suatu Pathet}

Kempyung adalah harmoni dua nada, antara suatu nada dengan nada kelima di atas atau di bawahnya (dalam laras pelog), atau bila terjadi pada laras slendro adalah antara suatu nada dengan nada keempat di atas atau di bawahnya. Secara teoretik menurut Koesumadinata (dalam Sadjijo, 1996: 85) kempyung ideal itu berkisar antara 710 cent -730 cent untuk laras slendro dan 630 cent- 690 cent untuk laras pelog.

Ada tiga macam pathet dalam laras slendro, yaitu pathet sanga dengan tonika nada 5 , pathet nem dengan tonika nada 2 , dan pathet manyura dengan tonika nada 6. Sedangkan pada laras pelog terdapat tiga macam pathet, yaitu pathet lima dengan tonika nada 5 , pathet nem dengan tonika pathet 2 , dan pathet barang dengan tonika nada 6.

\section{Cengkok dan Wiled}

Istilah cengkok dalam perspektif tembang Jawa mempunyai beberapa pengertian. Pertama, istilah cengkok berarti gaya. Berdasarkan pengertian in dikenal istilah-istilah tembang cengkok Banyumasan, cengkok Semarangan, cengkok Jawa Timuran, cengkok Surakarta, cengkok Yogyakarta, dan sebagainya, yang tidak lain adalah gaya dari masing-masing daerah tersebut di atas.

Pengertian kedua, cengkok berarti lagu. Dalam perspektif tembang Jawa, dikenal beberapa cengkok tembang macapat. Misalnya, dalam sekar sinom terdapat lagu grandhel, ginonjing, wenikenya, parijatha, dan logondang. Dalam sekar dhandhanggula dikenal adanya lagu banjet, baranglaya, kasepuhan, tlutur, pisowanan, penganten anyar dan sebangainya.

Pengertian yang ketiga, cengkok dipergunakan untuk menyebut wiled. Wiled adalah variasi nada dalam satu frase tembang. Wiled yang arah nadanya menjauhi tonika dinamakan wiled padhang, sedangkan wiled yang mendekati tonika dinamakan wiled ulihan

Secara teknis dalam karawitan, satu cengkok berarti satu gongan. Dalam konteks tembang Jawa, yang disebut dengan satu cengkok adalah satu padhang dan satu ulihan. Dalam sekar palaran/rambangan atau sekar gendhing, tanda satu cengkok ini sangat jelas karena adanya singgetan kendhang yang memberi aba untuk jatuhnya gong.

\section{Bentuk Lagu dalam Karawitan dan Tembang Jawa}

Secara umum lagu-lagu dalam karawitan Jawa ada tiga macam, yaitu lagu instrumentalia (gendhing), lagu vokal (tembang), dan lagu vokal instrumental (gabungan tembang dan gendhing). Berdasarkan bentuknya, gendhing-gendhing Jawa ada yang berstruktur beraturan dan tidak beraturan. Bentuk gending yang strukturnya beraturan dalam satu cengkoknya mempunyai struktur yang tetap, artinya dalam satu gongan gendhing selalu mempunyai ketukan (sabetan) yang sama, jumlah kenong, kempul, kethuk, dan kempyang yang sama (Mardimin, 1991: 47). Yang termasuk pada kategori ini adalah bentuk gendhing (1) lancaran, (2) ketawang, (3) ladrangan, (4) merong, yang terdiri dari merong ketawang gendhing kethuk 2 kerep, merong gendhing ketuk 2 kerep, gendhing 4 kerep, gendhing kethuk 8 kerep, gendhing kethuk 2 arang, dan gendhing kethuk 4 arang, (5) inggahinggah yang terdiri dari inggah kethuk 4, inggah kethuk 8, dan inggah kethuk 16.

Bentuk gendhing berstruktur tidak beraturan adalah bentuk komposisi karawitan Jawa yang dalam satu cengkoknya mempunyai struktur yang tidak tetap (Mardimin, 1991: 55). Yang termasuk dalam kategori ini adalah bentuk ayakayakan, srepegan, sampak, kemuda, dan bentuk-bentuk pamijen.

Bentuk-bentuk lagu vokal dalam karawitan Jawa ada bermacam-macam. Pembagian secara kasar akan menghasilkan kategori-kategori sulukan, sekar macapat, sekar tengahan, sekar ageng, lelagon dolanan, dan langgam Jawa dengan berbagai bentuknya. Masing-masing mempunyai ciri lagu yang sudah turun-temurun dan bersifat tradisional.

Bentuk-bentuk lagu vokal instrumental adalah bentuk sekar (tembang) yang dibuat sedemikian rupa dengan garap gendhingnya. Beberapa bentuk vokal instrumental dalam karawitan adalah gerongan, sindhenan srambahan, sindhenan sekar, sindhenan bedhaya srimpi,jineman, palaran, dan lelagon dolanan.

\section{Perkembangan Aspek Lirik}

Lirik atau syair dalam suatu lagu sesungguhnya adalah sesuatu karya sastra yang berbentuk puisi. Kekuatan suatu sajian musik, di samping ditentukan oleh lagunya (melodi, ritme, harmoni, tempo, dinamika, warna suara) juga ditentukan oleh kualitas sastra (lirik) nya. Kualitas tersebut bisa terbangun dari bentuknya, gaya bahasanya, maupun nilai-nilai yang terkandung di dalamnya.

Secara tradisional, bentuk-bentuk lagu/tembang itu sudah menpunyai 
kaidah estetika yang sudah baku. Akan tetapi, kadang-kadang seorang pencipta lagu belum puas dengan bentuk dan atau gaya bahasa yang dipergunakan secara tradisional tersebut. Kemampuan seseorang komponis untuk mengembangkan kaidah-kaidah tradisional tersebut akan menimbulkan sentuhan-sentuhan baru yang membuahkan daya tarik tersendiri.

Pada sisi yang lain, roh suatu karya seni terletak pada nilai apa yang ingin disampaikan kepada penikmatnya. Untuk itu diperlukan tanda-tanda tertentu yang dipahami bersama antara kreator lagu dan penikmatnya. Untuk membingkai pesan-pesan tersebut seorang pencipta lagu memerlukan tema-tema khusus.

\section{Konvensi Sastra dalam Lagu-lagu Jawa}

Konvensi adalah sesuatu yang tidak tertulis namun telah menjadi kebiasaan yang relatif tetap. Prawiradisastra (1996: 93-127) membagi konvens sastra lagu-lagu Jawa ke dalam dua hal, yaitu (1) konvensi bentuk, dan (2) gaya bahasa. Bentuk dasar sastra Jawa yang sudah berlaku secara tradisional dalam tembang-tembang Jawa dapat dibedakan menjadi sembilan, yaitu kakawin kidung, tembang gedhe, tembang tengahan,tembang macapat, parikan wangsalan, dan geguritan (Subalidinata, 1994: 18-51).

Kakawin adalah suatu gubahan sastra Jawa yang mempunyai ciri sebagai berikut: (1) setiap satu bait (padeswara) selalu terdiri dari empat baris (padapala) (2) setiap padapala selalu terdiri dari suku kata yang jumlahnya sama, dan (3) terikat oleh guru (Sanskerta: ghuru) artinya berat, dan lagu (Sanskerta: laghu) artinya ringan. Berat dan ringan tersebut diterapkan pada saat pembacaan sastra.

Kidung adalah puisi Jawa yang muncul pada jaman Majapahit (jaman Jawa tengahan). Istilah kidung artinya nyanyian (Subalidita: 1994: 23). Kidung bentuknya adalah sekar tengahan atau macapat dengan bahasa Jawa tengahan Bentuk ini terikat oleh guru lagu, guru wilangan, dan guru gatra.

Suluk adalah karya sastra yang mengandung isi tentang filsafat. Serat suluk ini muncul pada jaman Islam dan banyak dikembangkan oleh para wali. Contoh serat suluk adalah Suluk Wijil, Suluk Among Tani,dan Suluk Pangolahing Pangan. Dalam seni pertunjukan Jawa, khususnya dalam seni pedalangan dikenal pula istilah suluk akan tetapi mempunyai pengertian yang berbeda, yaitu lagu yang ditembangkan oleh dalang, meliputi ada-ada, sendhon, kawin, dan lagon.

Sekar Ageng adalah bentuk sastra tembang yang mempunyai ciri-ciri: terdiri dari 4 padapala, banyaknya wanda setiap padapala selalu tetap untuk setiap tembang yang dikenal dengan nama lampah. Terdiri dari dua padadirga dan tidak terikat oleh guru lagu. Secara fisik, sekar ageng sama dengan kakawin, akan tetapi bahasa yang dipergunakan adalah bahasa Jawa baru.

Sekar Tengahan, bila dilihat dari segi sastranya mempunyai ciri-ciri yang sama dengan sekar macapat, yaitu terikat oleh guru gatra, guru lagu, dan guru

Imaji, Vol.4, No.1, Februari 2006: 100 - 113 wilangan. Sedangkan bahasa yang dipergunakan adalah bahasa Jawa baru (Subalidinata, 1994: 29). Yang membedakan sekar tengahan dan sekar macapat adalah lagunya. Lagu sekar tengahan wilednya menyerupai lagu sekar ageng.

Sekar Macapat adalah sastra tembang yang paling popular di lingkungan masyarakat Jawa. Sekar macapat mempunyai ciri-ciri terikat oleh guru lagu, guru wilangan, dan guru gatra. Bahasa yang dipergunakan adalah bahasa Jawa baru dengan sedikit hiasan bahasa Kawi.

Parikan adalah salah satu bentuk sastra Jawa yang mempunyai ciri-ciri: (1) satu pada terdiri dari atas 4 gatra (atau dua gatra), (2) purwakanthi (persajakannnya) a b a b, dan (3) gatra pertama dan kedua sebagai sampiran, sedangkan gatra ketiga dan keempat sebagai isi. Dalam sastra Sunda juga dikenal jenis yang sama yang disebut dengan nama peparikan yang merupakan salah satu bentuk sesindiran.

Wangsalan adalah salah satu bentuk sastra Jawa yang mirip dengan parikan, akan tetapi mengandung cangkriman dan tebakan. Bentuk wangsalan ini banyak digunakan dalam seni karawitan, terutama pada bentuk sindenan srambahan.

Dalam seni pertunjukan, sembilan bentuk dasar sastra tersebut telah diolah menjadi bentuk-bentuk tembang lagi yang sudah menjadi tradisional, yaitu bawa, sindhenan, gerong, palaran, sekar gendhing, sekar cakepan, jineman, sulukan, dan langgam Jawa.

\section{E. Lagu Campursari dalam Perspektif Tembang Jawa}

Suatu komposisi lagu merupakan gubahan yang memadukan unsur-unsur melodi, ritme, dan warna suara dalam bentuk-bentuk karya yang dinamis dengan dihiasi dengan lirik-lirik lagu yang sesuai dengan tema yang digarap.Dengan pendekatan estetika identitas, lagu campur sari dicoba dilihat dari perspektif bentuk tembang Jawa yang sudah ada, yaitu didekati dari aspek laras, pathet, cengkok/wiled, dan struktur lagu.

Secara umum Manthous menggunakan dua macam laras di dalam lagulagunya, yaitu laras slendro (29\%)dan laras pelog bem (71\%). Secara rinci laras yang dipergunakan dalam lagu-lagu campursari ciptaan Manthous adalah sebagai berikut: 
Tabel 2. Laras yang Dipergunakan dalam Lagu Campursari Manthous

\begin{tabular}{|c|c|l|c|c|}
\hline NO & LARAS & \multicolumn{1}{|c|}{ NAMA LAGU } & \multicolumn{2}{|c|}{ JUMLAH } \\
\hline 1 & Slendro & $\begin{array}{l}\text { Bengawan sore, gethuk, tahu apa tempe, } \\
\text { klemben-klemben roti-roti, pipa landa, } \\
\text { mbah dukun, othok kowouk }\end{array}$ & 7 & $29 \%$ \\
\hline 2 & Barang Miring & - & 0 & $0 \%$ \\
\hline 3 & Pelog Bem & $\begin{array}{l}\text { Kempling, aja digondheli, aja gawe- } \\
\text { gawe, kanca tani, pripun, Gunung Kidul, } \\
\text { Andheng-andheng, Anting-anting, } \\
\text { Parangtritis, Nginang karo Ngilo, } \\
\text { Simpang Lima, Geblek Kulon Progo, } \\
\text { Methuk, Esemmu, Sluman-slumun } \\
\text { slamet, Lega, kembang kecubung, dan } \\
\text { Sida Apa Ora. }\end{array}$ & 17 & $71 \%$ \\
\hline 4 & Pelog Barang & & 0 & $0 \%$ \\
\hline
\end{tabular}

Pemilihan laras slendro dan pelog bem dalam lagu-lagu campursari Manthous merupakan kelanjutan tradisi pada langgam Jawa yang juga lebih banyak menggunakan laras yang sama. Kalau dikaji secara teknis, sesungguhnya memadukan pelog bem dan pelog barang dengan musik diatonis Bara mempunyai tingkat kesulitan yang sama karena gamelan campursari itu telah dibuat sedemikian rupa menggunakan frekuensi musik Barat, maka di antara keduanya mempunyai jarak nada yang sama seperti pada Tabel 3. Akan tetapi, penggunaan laras pelog barang relatif memerlukan suara agak tinggi karena tonikanya nada 3 (lu), jauh lebih tinggi dibandingkan dengan pelog bem yang menggunakan tonika nada 6 (nem). Lain halnya dengan tidak dipilihnya laras Barang Miring. Secara teknis penggunaan laras ini lebih sulit dibandingkan dengan laras slendro, pelog barang, maupun pelog bem. Ada beberapa nada yang tidak ditemukan pada instrumen, yaitu nada-nada tengahan yang tingginya kalau dalam karawitan Jawa hanya bisa diwujudkan oleh suara tembang dan bunyi gesekan rebab.

Imaji, Vol.4, No.1, Februari 2006: 100 - 113
Tabel 3 Konversi nada-nada laras pelog bem dan laras pelog barang ke dalam tangga nada Barat

\begin{tabular}{|l|l|l|l|l|l|l|}
\hline Tangga Nada & \multicolumn{7}{|c|}{ Nada Konversi } \\
\hline Musik Barat & $\mathbf{1}$ & $\mathbf{3}$ & $\mathbf{4}$ & $\mathbf{5}$ & $\mathbf{7}$ & $\mathbf{1}$ \\
\hline Dibaca & $d o$ & $m i$ & $f a$ & $s o l$ & $s i$ & $d o$ \\
\hline Laras Pelog Bem & $\mathbf{6}$ & $\mathbf{1}$ & $\mathbf{2}$ & $\mathbf{3}$ & $\mathbf{5}$ & $\mathbf{6}$ \\
\hline Dibaca & $n e m$ & $j i$ & $r o$ & $l u$ & $m a$ & $n e m$ \\
\hline Laras Pelog Barang & $\mathbf{3}$ & $\mathbf{5}$ & $\mathbf{6}$ & $\mathbf{7}$ & $\mathbf{2}$ & $\mathbf{3}$ \\
\hline Dibaca & $l u$ & $m a$ & $n e m$ & $p i$ & $r a$ & $l u$ \\
\hline
\end{tabular}

Pada laras pelog, lagu-lagu campursari Manthous hanya menggunakan satu macam pathet, yaitu pathet 6 dengan do sama dengan 6 (nem), sedangkan pada laras slendro, pathet yang dipilih hanya satu yaitu pathet Sanga dengan tonika 5. Pemilihan dua macam pathet ini kalau dikaji lebih disebabkan oleh konsekuensi logis dari penyesuaian frekuensi nada-nada gamelan dengan frekuensi musik Barat seperti pada gamelan campursari. Masing-masing laras (pelog dan slendro) hanya mungkin dimainkan dengan dua nada dasar, yaitu pada laras slendro adalah $\mathrm{do}=1$ (ji) dan $\mathrm{do}=5$ (lima). Sedangkan pada laras pelog hanya mungkin dimainkan nada dasar $\mathrm{do}=6(\mathrm{nem})$ atau $\mathrm{do}=3(\mathrm{lu})$. Hal ini bisa dijelaskan dengan memperhatikan interval nada-nada gamelan campursari sebagai berikut:

Tabel 4 Penggunaan Nada Dasar dalam Laras Pelog dan

Slendro Musik Campursari

\begin{tabular}{|c|c|c|c|c|c|c|c|c|c|c|c|c|c|}
\hline Diatonis Barat & 1 & 2 & 3 & 4 & 5 & 6 & 7 & 1 & & 2 & 3 & 4 & 5 \\
\hline Interval & & & 200 & 100 & 200 & 200 & 200 & 100 & 200 & & $\begin{array}{ll}00 & 100 \\
\end{array}$ & & 00 \\
\hline Pelog 1 (cp sr) & 1 & - & 3 & 4 & $\overline{5}$ & - & 7 & 1 & & & & & \\
\hline Pelog 2 (cp sr) & & & & & 5 & - & 7 & 1 & & 2 & - & 3 & 5 \\
\hline Slendro 1 (cp sr) & 1 & 2 & 3 & - & 5 & 6 & - & 1 & & & & & \\
\hline Slendro 2 (cp sr) & & & & & 5 & 6 & 7 & - & & 2 & 3 & - & 5 \\
\hline
\end{tabular}

Pada laras Pelog, deretan interval 400-100-200-400-100 hanya mungkin dimainkan dengan dua macam cara, yaitu dengan nada-nada do-mi-fa-sol-si-do atau sol-la-si-do-re-mi yang dalam laras pelog (campursari) identik dengan nemji-ro-lu-ma-nem atau lu-ma-nem-ji-ro-lu. Dua kemungkinan nada dasar tersebut dalam karawitan Jawa termasuk dalam pathet nem.

Pada laras slendro, untuk menyusun deretan interval 200-200-300-200300 hanya mungkin dilakukan dengan dua cara, yaitu: do-re-mi-sol-la-do atau solla-si-re-mi-sol yang dalam laras slendro (campursari) identik dengan ji-ro-lu-manem-ji atau ma-nem-ji-ro-lu-ma. Dua macam nada dasar tersebut termasuk dalam pathet sanga dalam gamelan Jawa.

Berdasarkan struktur fisiknya, lagu-lagu campursari Manthous terdiri

Melodi dan Lirik Lagu Campursari Ciptaan Manthous (Kusnadi) 
dari tiga macam bentuk, yaitu (1) langgam Jawa konvensional, (2) lelagon kreasi baru, dan (3) campuran antara keduanya. Beberapa bentuk lagu yang menggunakan langgam Jawa konvensional adalah Bengawan Sore, Aja Digondeli, Aja Gawe-gawe, Kanca Tani, Pripun, Andheng-andheng, Anting-anting, Esemmu Lega, dan Kembang Kecubung. Yang masuk kategori lelagon kreasi baru adalah Kempling, Parangtritis, Tahu apa Tempe, Klemben-klemben Roti-roti, Pipa Landa, Nginang Karo Ngilo, Simpang Lima, dan Mbah Dukun. Sisanya merupakan bentuk campuran antara keduanya.

Membandingkan langgam Jawa ciptaan Manthous dengan bentuk langgam Jawa konvensional yang ada sebelumnya misalnya langgam "Yen ing Tawang Ana Lintang" ciptaan Anjar Ani ternyata ada kesamaan strukturnya Secara umum, struktur langgam Jawa di samping ditunjukkan oleh iramanya juga urutan lagunya, yaitu introduksi-A1-A2-A3-interlude-A1-A2-coda. Pada bagian introduksi Manthous menggunakan beberapa pola, yaitu (1) introduks konvensional yang didalam karawitan Jawa dikenal dengan istilah buka (2) bawa khususnya pada Langgam Kanca Tani. Bedanya, bawa pada lagu ini dengan bawa pada karawitan adalah bawa Kanca Tani ini berdiri sendiri, tidak langsung diterima oleh gendhing. Sehingga setelah bawa tidak dilanjutkan celuk akan tetapi dilanjutkan introduksi musik, (3) menggunakan umpak (interlude) yaitu sajian instrumentalia yang melodinya menggunakan melodi satu bait lagu, biasanya diambilkakn dari A2. inovasi lain yang dilakukan Manthous pada lagu langgamnya adalah variasi liriknya pada lagu bagian B. pada bagian ini Manthous tidak hanya menggunakan pola konvensional satu bait lagu B, akan tetapi sering dua bait.

Lagu-lagu yang berbentuk lelagon kreasi baru ciptaan Mantous menurut penulis banyak dipengaruhi oleh model-model lagu ciptaan Ki Narta Sabda Struktur penyajiannya dibuat agak bebas meskipun masih tetap berpola pada struktur lagu pada umumnya. Secara konvensional lagu-lagu dolanan pada karawitan Jawa itu strukturnya adalah umpak A1-A2-B yang dilakukakn secara berulang-ulang, selain itu iramanya berbentuk irama lancar. Contoh model lelagon yang sangat konvensional adalah Kempling dan Parangtritis yang menggunakan pola di atas. Pada lagu-lagu Manthous, introduksi bisa berupa umpak (interlude) akan tetapi bisa juga mengambil sedikit melodi lagu (buka). Sedangkan lagu bagian B umumnya 2 cengkok.

Bentuk yang ketiga pada lagu-lagu Manthous adalah bentuk campuran. Yang dimaksud dengan bentuk campuran adalah suatu bentuk lagu yang memilik ciri-ciri baik pada langgam Jawa maupun lelagon dolanan. Campuran di sin terutama terjadi pada urutannya maupun irama penyajiannya. Sebagai contoh adalah lagu gethuk dan lagu methuk. Pada lagu ini, pada bagian A disajikan sepert pada langgam Jawa, akan tetapi ketika memasuki bagian B iramanya diubah seperti lelagon dolanan.

Coda adalah melodi khusus yang dipergunakan untuk menutup lagu. Coda ini dalam lagu-lagu ciptaan Manthous tidak terikat pada satu pola tertentu. Bahkan coda penutup tidak selalu ada. Beberapa lagu ciptaannya diakhiri dengan model seperti suwuk pada karawitan Jawa, yaitu berakhirnya sajian musik pengiring bersama-sama dengan habisnya lagu. Model-model seperti ini tampak pada lagu Kempling, Aja Digondheli, Aja Gawe-gawe, Gethuk, Kangen, Kanca Tani, Pripun, dan Gunung Kidul.

Pemahaman yang baik Manthous terhadap sastra Jawa memungkinkan Manthous dengan leluasa di dalam menyusun lirik-lirik lagunya. Pemilihan katakata yang halus pada lagu-lagu bentuk langgam ciptaannya merupakan salah satu cirri khasnya. Meskipun ada lagu-lagu ciptaan Manthous yang menggunakan basa karma, namun sebagian besar ciptaannya menggunakan basa ngoko. Hal menurut pengamatan penulis adalah agar lagu-lagu tersebut lebih komunikatif dan merakyat. Lagu yang menggunakan basa karma adalah pripun dan mbah dukun. Lagu-lagu yang menggunakan basa ngoko dapat dibagi menjadi dua bentuk yaitu ngoko alus dipergunakan untuk lagu-lagu langgam Jawa, dan ngoko padintenan dipergunakan untuk lagu-lagu kreasi baru (lelagon).

Salah satu ciri terpenting dari lirik-lirik lagu ciptaan Manthous adalah digunakannya bentuk purwakanthi guru swara pada semua lagu ciptaannya. Bentuk penerapannya bervariasi. Ada yang diletakkan pada setiap akhir baris maupun pada setiap kata yang digunakan.

Pola persajakan yang dipilih Manthous sangat variatif. Ada yang menggunakan pola a-a-a-a, a-b-a-b, ada pula a-a-b-b. Untuk mencapai tuntutan persajakan itu Manthous tidak segan-segan menyingkat kata (wancahan) dan mengubah bunyi huruf hidup pada akhir gatra seperti yang biasa dilakukan pada pembuatan cakepan tembang Jawa tradisional. Di samping itu, parikan dan wangsalan merupakan bentuk yang banyak dipilih oleh Manthous dalam memperindah lirik-lirik lagunya. Sebagian besar penerapan parikan tersebut adalah pada bagian frase B lagu-lagunya. Sampiran parikan tersebut beberapa di antaranya di jadikan judul, misalnya pada lagu Gethuk dan Andheng-andheng.

Pada beberapa lagunya, Manthous memasukkan ungkapan-ungkapan tradisional Jawa seperti "witing trisna jalaran saka kulina" "kriwikan dadi grojogan". Ungkapan-ungkapan ini mencerminkan isi lirik yang diuraikan dalam keseluruhan lagu. Di samping itu, juga dipergunakan gaya bahasa metafora yang cukup menarik, misalnya pada lagu esemm $и$ dipergunakan ungkapan segara madu untuk menggambarkan manisnya wajah, dan wong lumampah tur kasatan toya pada lagu lega untuk menggambarkan hausnya seseorang akan cinta kasih. 
Tema-tema yang diangkat Manthous sebagian besar adalah tema cinta, baik untuk kalangan remaja maupun orang dewasa. Di samping itu, Manthous juga mengangkat tema tentang keindahan alam dan budaya masyarakat seperti pada lagu Gethuk, Parangtritis, dan Gunung Kidul, kehidupan petani, dan kehidupan berumah tangga.

\section{F. Penutup}

Berdasarkan bentuk lagunya, lagu-lagu campursari ciptaan Manthous masih mengacu pada gendhing-gendhing dan lagu tradisional khususnya langgam Jawa konvensional, lelagon dolanan, atau campuran keduanya. Pada langgam Jawa Mantous menggunakan beberapa pola introduksi, yaitu (1) introduks konvensional, (2) bawa, dan (3) umpak. Kreasi pada tubuh lagu adalah pada bagian B yang tidak hanya terpaku menggunakan satu cengkok akan tetapi juga dua cengkok. Variasi pada penutup lagu ada dua macam, yaitu (1) menggunakan coda, (2) tanpa coda tetapi menggunakan pola suwuk pada karawitan Jawa.

Tangga Nada yang paling banyak dipergunakan dalam lagu-lagu Mantous adalah Pelog Bem dan Slendro. Secara teknis, memadukan pelog bem dan pelog barang dengan musik diatonis Barat mempunyai tingkat kesulitan yang sama karena gamelan campursari itu telah dibuat sedemikian rupa menggunakan frekuensi musik Barat, maka di antara keduanya mempunyai jarak nada yang sama seperti pada Tabel 3. Akan tetapi, penggunaan laras pelog barang relatif memerlukan suara agak tinggi karena tonikanya nada 3 (lu), jauh lebih tingg dibandingkan dengan pelog bem yang menggunakan tonika nada 6 (nem). Lain halnya dengan tidak dipilihnya laras Barang Miring. Secara teknis penggunaan laras ini lebih sulit dibandingkan dengan laras slendro, pelog barang, maupun pelog bem. Ada beberapa nada yang tidak ditemukan pada instrumen, yaitu nadanada tengahan yang tingginya kalau dalam karawitan Jawa hanya bisa diwujudkan oleh suara tembang dan bunyi gesekan rebab. Sedangkan pathet yang dipilih kebanyakan adalah Pelog pathet Nem dan Slendro pathet Manyura.

Hiasan sastra yang paling dominan dipergunakan pada lirik-lirik lagu campursari Manthous adalah purwakanthi guru swara kemudian parikan, wangsalan, wancahan, mengubah huruf hidup pada akhir gatra, dan menyelipkan ungkapan-ungkapan tradisional, adanya senggakan dan bebasan paribasan. Sedangkan pola persajakannya ada tiga macam a-a-a-a , a-b-a-b, dan a-a-b-b. Bahasa Jawa yang dipergunakan pada lagu-lagu Manthous adalah Basa Jawa Ngoko baik halus maupun basa padintenan, basa krama hanya dipergunakan pada dua lagu ciptaannya, yaitu pripun dan mbah dukun. Tema yang paling dominan dari lagu-lagu campursari karya Manthous adalah tema cinta, hubungan suami istr dalam rumah tangga, keindahan alam dan kehidupan masyarakat. Hal ini disesuaikan dengan sasaran lagu-lagu Manthous adalah kalangan remaja dan orang dewasa.

Imaji, Vol.4, No.1, Februari $2006: 100$ - 113
DAFTAR PUSTAKA

Atmadarsana, F. 1956. Mardawa Swara. Semarang: Yayasan Kanisius

Gitosaprodja. 1971. Ichtisar Teori Sindenan. Malang: RRI Malang

Kusnadi. 1999. Pengantar Apresiasi Tembang Jawa. Yogyakarta: FBS Universitas Negeri Yogyakarta

La Meri . 1975. Dance Compotion: The Basic Elemen (terjemahan Soedarsono). Yogyakarta: ASTI

Manthous. 1999. "Campursari”. Makalah Sarasehan. Yogyakarta: Taman Budaya Yogyakarta

Mardimin, Y. 1991. Karawitan Dasar. Salatiga: Duta Wacana.

Prawiradisastra, Sadjijo. 1996. Pengantar Awal Apresiasi Seni Tembang. Yogyakarta: FPBS IKIPYogyakarta

Prier, Karl Edmund. 2001. Ilmu Harmoni. Yogyakarta: Pusat Musik Liturg

Siswanto. M. 1978. Pengetahuan Karawitan. Yogyakarta: SMKI Konri

Subalidinata. 1994. Kawruh Kasusastraan Jawa. Yogyakarta:Yayasan Pustaka Nusatama

Supomo. 1991. "Kama di dalam Kakawin" dalam Sutrisno Sulastin. 1991. Bahasa Sastra Budaya. Yogyakarta: Gamapres

Susena, Agus. 1999. "Campursari, Musik Akulturasi dalam Proses". Makalah Sarasehan Budaya. Yogyakarta: Taman Budaya Nusantara

Suryadiningrat. 1993. Tone Measurement of Outstanding Javanese Gamelans in Yogyakarta and Surakarta. Yogyakarta: Gama Press. 